\title{
Case Report of Dramatic Resolution of Psychotic Symptoms During Cross-Over to Clozapine
}

\author{
Leo Sher M.D. \\ National Institute of Mental Health, Bethesda, MD; Hillside Hospital, Psychiatric Division of Long Island \\ Jewish Medical Center, the Long Island Campus for the Albert Einstein College of Medicine, Glen Oaks, \\ NY
}

Alan Mendelowitz M.D. Hillside Hospital, Psychiatric Division of Long Island Jewish Medical Center, the Long Island Campus for the Albert Einstein College of Medicine, Glen Oaks, NY; Albert Einstein College of Medicine, Bronx, NY

Follow this and additional works at: https://jdc.jefferson.edu/jeffjpsychiatry

Part of the Psychiatry Commons

Let us know how access to this document benefits you

\section{Recommended Citation}

Sher, Leo M.D. and Mendelowitz, Alan M.D. (1999) "Case Report of Dramatic Resolution of Psychotic Symptoms During Cross-Over to Clozapine," Jefferson Journal of Psychiatry. Vol. 14 : Iss. 2 , Article 8. DOI: https://doi.org/10.29046/JJP.014.2.008

Available at: https://jdc.jefferson.edu/jeffjpsychiatry/vol14/iss2/8

This Article is brought to you for free and open access by the Jefferson Digital Commons. The Jefferson Digital Commons is a service of Thomas Jefferson University's Center for Teaching and Learning (CTL). The Commons is a showcase for Jefferson books and journals, peer-reviewed scholarly publications, unique historical collections from the University archives, and teaching tools. The Jefferson Digital Commons allows researchers and interested readers anywhere in the world to learn about and keep up to date with Jefferson scholarship. This article has been accepted for inclusion in Jefferson Journal of Psychiatry by an authorized administrator of the Jefferson Digital Commons. For more information, please contact: JeffersonDigitalCommons@jefferson.edu. 


\title{
Case Report of Dramatic Resolution of Psychotic Symptoms During Cross-over to Clozapine
}

\author{
Leo Sher, M.D. and Alan Mendelowitz, M.D.
}

\begin{abstract}
Clozapine is the first antipsychotic drug with proven superiority over conventional antipsychotics in the management of treatment-resistant patients. We describe a case of treatment-resistant schizoaffective disorder in a young woman who improved rapidly on clozapine. The patient was started on a low dose of clozapine while fluphenazine was decreased. She improved significantly during the first several days of treatment. This improvement took place well before the expected effect of clozapine. Possible explanations for this unusual response include: 1) the placebo effect; 2) fluphenazine dose-response curve; 3) acute clozapine neurochemical mechanisms; 4) inaccurate original diagnosis. Better understanding of the mechanisms of action of antipsychotic drugs may considerably improve patient care.
\end{abstract}

Clozapine is the first antipsychotic agent with proven superiority over conventional antipsychotics in terms of its efficacy in treatment-resistant patients $(1,2)$. In patients with poor or partial response to conventional neuroleptics, clozapine is the treatment of choice. We wish to report and to discuss a case of the rapid and substantial improvement of a patient who was started on clozapine.

\section{PRESENTING PROBLEM AND PATIENT DESCRIPTION}

Ms. C. was a 34 year old white Jewish female with 13 year history of schizoaffective disorder. At the time of admission the patient reported auditory hallucinations, referential delusions (the patient felt that other people were making reference to her), and the belief that she was able to read the minds of people around her. The

Leo Sher, M.D. is a fellow at the National Institute of Mental Health, Bethesda, Maryland. At the time of writing this article, he was a resident at Hillside Hospital, Psychiatric Division of Long Island Jewish Medical Center, the Long Island Campus for the Albert Einstein College of Medicine, Glen Oaks, New York.

Alan Mendelowitz, M.D. is Chief of the Residency Training and Research Unit at Hillside Hospital, Psychiatric Division of Long Island Jewish Medical Center, the Long Island Campus for the Albert Einstein College of Medicine, Glen Oaks, New York, and Assistant Professor of Psychiatry, Albert Einstein College of Medicine, Bronx, New York.

The corresponding author: Leo Sher, M.D., NIMH, Bldg. 10, Rm 3S-231, 9000 Rockville Pike, Bethesda, MD 20892, Tel: 301-496-2141, Fax: 301-496-5439, E-mail: LSHER@BOXL.NIH.GOV 
patient also reported sad mood and some anxiety. She was tearful with a constricted affect. Ms. C. showed good insight into her illness (she was aware of her illness, and understood that her symptoms and social problems were due to her own disturbances), and expressed a strong desire to get rid of her symptoms. This, despite the fact that the male voice which was "talking to her" sounded friendly. (She stated that the ability to hear this voice was abnormal.) During the initial interview Ms. C. also displayed some dependent features including the needs for her parents to assume responsibility for decisions in her life. We had an opportunity to interview the patient's parents and learned that the patient always had dependent traits.

\section{BACKGROUND INFORMATION}

Ms. C. did well academically in the Elementary, Junior High, and High Schools. She skipped two school years and graduated from the High School in 10 years instead of 12 years. She entered the College, and she was close to completing her Bachelor Degree, when at the age of 21 , Ms. C. developed psychotic symptoms including auditory hallucinations and ideas of reference. Her level of functioning declined considerably, and the patient had to drop out of the College. The patient was hospitalized once at the time of her first break, and then she has been in outpatient treatment for 13 years. The course of her illness was somewhat unusual: it went for 13 years from onset to the first considerable relapse. She has been on haloperidol for a long time with a partial response (the level of her social functioning was low, and, sometimes, she had mild psychotic symptoms). Six months prior to admission, the patient's condition deteriorated, she developed persistent auditory hallucinations and referential delusions, and she was switched from haloperidol to fluphenazine. Fluphenazine was gradually increased to $40 \mathrm{mg} /$ day. However, the clinical response was temporary and limited. The patient continued to deteriorate, and her psychiatrist referred her to the hospital for inpatient treatment.

\section{HOSPITAL COURSE}

Ms. C. was evaluated and felt to meet criteria for nonresponse to standard antipsychotic treatment, and was offered clozapine treatment. She was told that clozapine was a very effective drug, it helped many patients, who were partial responders, and that it could improve the patient's quality of life. Ms. C. agreed with considerable enthusiasm. On the first day of the treatment she received $12.5 \mathrm{mg}$ of clozapine while fluphenazine was tapered to $20 \mathrm{mg}$. On the next day the patient reported improvement, stating that her auditory hallucinations were less disturbing, and that she was free of the hallucinations for two hours in the morning. On the fifth day of the treatment, when the clozapine dose was $25 \mathrm{mg}$ bid and fluphenazine dose continued at $20 \mathrm{mg} / \mathrm{day}, \mathrm{Ms}$. C. reported marked improvement, the patient stated that she felt much better, totally free from referential ideas. She reported that the hallucinatory voice was quiet, less disturbing, and a part of the day she did not hear it at all. She also felt relief from anxiety. Over the following days Ms. C. reported 
improvement almost every day, she tolerated clozapine well, and three weeks after her admission she was discharged with very considerable improvement. At the time of discharge patient was not getting fluphenazine, and her clozapine dose was 200 $\mathrm{mg} / \mathrm{day}$.

\section{DISCUSSION}

This quick and remarkable response to clozapine treatment in this patient requires further evaluation. It can be explained in part by a placebo effect which is probably involved in every therapeutic maneuver. A number of factors which may predict a good response in this patient may include the patient's strong desire to get better, relatively good insight into her illness, a relatively high level of education, the patient's high degree of suggestibility, the presence of dependent personality features, the desire to be a "good patient," and the fact that the medication was given by caring and confident physicians could contribute to this effect.

The "placebo effect" is an outstanding example of mind-body relationships, a case of transformation of psychological effects into biological processes $(3,4)$. Patients with schizophrenia may respond to placebos (5-8). A striking dependence on a placebo in a periodically catatonic schizophrenic woman has been reported in the literature (5). An unexpected placebo response was found during a double-blind drug study in a patient with treatment-resistant tardive diskinesia (6). Schulz and colleagues reported an excessive beta-endorphin response to placebo in schizophrenic patients (7). Pickar and associates found increases in plasma opioid activity after the intravenous administration of placebo in patients with schizophrenia (8).

In 1978 Levine and associates who studied the analgesic effect of placebo proposed that endorphin release mediates a placebo response (9). Several studies were conducted to test the hypothesis that beta-endorphins are endogenous substances with neuroleptic-like activity and that disturbances in the beta-endorphin fragmentation may contribute to the pathogenesis of psychotic disorders (10-12). These studies showed that endorphins can possess neuroleptic properties. Hence, it can be argued that placebo may cause a release of endogenous substances with neuroleptic-like activity and produce an antipsychotic effect.

Decrease in fluphenazine dose could also play a part in the patient's quick and substantial improvement. Clinical information on the therapeutic dosage of antipsychotics remains controversial. It has been proposed that neuroleptics may have a bell-shaped dose-response curve (13). Possibly, in this case $20 \mathrm{mg}$ of fluphenazine per day could give a better clinical response than $40 \mathrm{mg} /$ day. It is also possible that decrease in fluphenazine caused reduction in extrapyramidal symptoms, and the improvement was from the decrease in these symptoms.

Another possible explanation can be connected with monoamine and amino acid transmission in different brain regions after acute clozapine administration. The experiments on rats showed that the acute administration of $10-30 \mathrm{mg} / \mathrm{kg}$ of clozapine increased dopamine and glutamate in the medial prefrontal cortex, and produced a greater increase compared with haloperidol, in gamma-aminobutyric acid 
efflux within the ventral pallidum (14). These changes were observed 1-2 hours after the clozapine administration. Combined dysfunction of dopamine and N-methyl-Daspartate glutamate receptors with the involvement of GABAergic neurons has been implicated in pathophysiological mechanism of schizophrenia, and it has been suggested that some antipsychotic drugs, including clozapine, can prevent these pathological changes in the brain (15).

There is a possibility that the original diagnosis was inaccurate. The unusual course of the patient's illness (it went for 13 years from onset to first serious relapse) and the unusually rapid improvement after the inpatient admission might be related to the incorrect original diagnosis.

\section{CONCLUSION}

Over the past decades we have witnessed considerable progress in the psychopharmacological treatment of psychotic disorders. Antipsychotic medications help many patients. Better understanding of the mechanisms of action of psychotropic drugs may significantly improve patient care.

\section{REFERENCES}

1. Kane J, Honigfeld G, Singer J, Meltzer H: Clozapine for the treatment-resistant schizophrenic: A double-blind comparison with chlorpromazine. Arch Gen Psychiatry 1988; 45: 789-796.

2. Umbricht DSG, Lieberman JA, Kane JM: The clinical efficacy of clozapine in the treatment of schizophrenia. Rev Contemp Pharmacother 1995; 6: 165-186.

3. Sher L: The placebo effect on mood and behavior: the role of the endogenous opioid system. Med Hypotheses, 1997; 48: 347-349.

4. Shapiro AK, Morris LA: The placebo effect in medical and biological therapies. In: Handbook of Psychotherapy and Behavioral Change: An Empirical Analysis. Eds. Garfield SL, Bergin AE. 2nd edn. John Wiley \& Sons, New York, 1978, pp. 369-410.

5. Vinar O: Dependence on a placebo: A case report. BrJ Psychiatry 1969; 115: 1189-1190.

6. Remington G, Fornazzari L, Setlma R: Placebo response in refractory tardive akathisia. Can J Psychiatry 1993; 38: 248-250.

7. Schulz SC, van Kammen DP, Pickar D, Cohen MR, Naber D: Response of plasma beta-endorphin immunoreactivity to d-amphetamine and placebo in schizophrenic patients. Psychiatry Res 1982; 7: 171-178.

8. Pickar D, Davis GC, Schulz SC, et al: Behavioral and biological effects of acute betaendorphin injection in schizophrenic and depressed patients. Am J Psychiatry 1981; 138: 160-166.

9. Levine JD, Gordon NC, Fields HL: The mechanism of placebo analgesia. Lancet 1978; 2: 654-657.

10. Verhoeven WM, Westenberg HG, Gerritsen TW, et al: (Des-tyrosine 1)-gamma-endorphin in schizophrenia: clinical, biochemical, and hormonal aspects. Psychiatry Res 1981; 5: 293-309.

11. Verhoeven WM, van Ree JM, Heezius van Bentum A, et al: Antipsychotic properties of Des-enkephalin-gamma-endorphin in treatment of schizophrenic patients. Arch Gen Psychiatry 1982; 39: 648-654. 
12. Verhoeven WM, van Ree JM, Westenberg HG, et al: Clinical, biochemical, and hormonal aspects of treatment with Des-tyrlgamma-endorphin in schizophrenia. Psychiatry Res 1984; 11: 329-346.

13. Kaplan HI, Sadock BJ, Grebb JA: Kaplan and Sadock's synopsis of psychiatry: behavioral sciences, clinical psychiatry. 7th ed. Baltimore: Williams \& Wilkins, 1994, pp. 956-959.

14. Yamamoto BK, Pehek EA, Meltzer HY: Brain region effects of clozapine on amino acid and monoamine transmission. J Clin Psychiatry 1994; 55 Suppl B: 8-14.

15. Olney JW, Farber NB: Glutamate receptor dysfunction and schizophrenia. Arch Gen Psychiatry 1995; 52: 998-1007. 